\title{
ANALYSIS OF CRITICAL DISCUSSION IN THE ARTICLE "DIFFERENT FATE: THR CIVIL SERVANTS IN THIS WEEK, THR OF LIVERS POSTPONED AND INSTALLED" (Kompas, 11 Mei 2020)
}

\author{
Muhammad Misbahul Huda \\ Sunan Kalijaga State Islamic University, Yogyakarta \\ Email: hudamisbahul100297@gmail.com
}

\begin{abstract}
The focus of this research is (a) describing the dimensions of the text, (b) describing discursive practices, (c) describing socio-cultural praxis, and assumptions of social irregularities through obstacles and how to overcome these obstacles, based on Kompas 11 May 2020 Edition. with the title "Difference in Fate: THR PNS Liquided This Week, THR Labor Delayed and Installed. This type of research uses library research, while data collection uses documentation, and Norman Fairclough's Critical Discourse Analysis (AWK) as a tool for analysis. Based on the research, the following results were obtained: (a) the dimensions of the text. The text in the Kompas report seems to speak of a clear caste difference between civil servants and workers. (b) dimensions of discursive practice. Besides the existence of Covid19, Circular Letter about the THR of workers that can be postponed or paid in installments and the news about the THR PNS immediately disbursed, explicitly indicates that there are social irregularities that occur. (c) socio-cultural praxis dimensions. With this news, it triggers the reaction of the workers / laborers to launch a demonstration, either through the leadership of workers throughout Indonesia or even there will be a demonstration going down. While the assumptions of social irregularities can be seen in the inequality and discrimination of workers / laborers caused by the government. The government seems to favor the civil servants and company owners. This can be prevented by ensuring that the THR of workers is controlled up to the hands of the workers, and that the Circular Letter will instead be used as a weapon for company owners so that they do not meet the workers' THR, this requires the supervision of the government.
\end{abstract}

Keywords: Critical Discourse Analysis, Norman Fairclough, Covid-19, Labor, Kompas.com

\section{INTRODUCTION}

Since its appearance at the end of 2019, the COVID-19 virus has spread throughout the world. The global economic slowdown has begun to be felt at home due to the rapid spread of COVID-19. Moody's Investors Service predicts that Indonesia's economic growth in 2020 will experience a slowdown at $4.8 \%$ of the Gross Domestic Product (GDP). The existence of COVID-19 also has an impact on the economic sector, so it can be said that the economic sector is in the worst category which impacts the industrial sector. 
Many companies have finally implemented a new work system. A work system that is done at home (work from home) as a rule imposed by the government. Not only the work system, companies are also forced to terminate their workers (laborers). Chairman of the Task Force for the Acceleration of Handling Covid-19, Doni Monardo, noted that there were 1.6 million workers (laborers) who were laid off.

Not finished with the dismissal of workers, workers who were still working at the company were shocked by the existence of a Circular (SE) from the government on May 6, 2020, through the Minister of Manpower of the Republic of Indonesia, Ida Fauziyah explaining that, the payment of Religious Holiday Allowances (THR) from entrepreneurs to workers/labor can be done in stages or postponed. The Circular Letter states that there is a need for understanding between employers and workers/laborers in facing the crisis caused by Covid-19.

The holiday allowance (THR) for workers/laborers is something that is very extraordinary, especially considering the current crisis. It is certain that this allowance can help workers/laborers and their families. However, there is a striking difference in the news about the holiday allowance (THR) for civil servants that can be disbursed. The news was delivered directly by the Minister of Finance of the Republic of Indonesia, Sri Mulyani. This can be found in the news published in one of the Kompas newspapers May 11, 2020 with the title "Different Fate: THR for Civil Servants This Week, THR for Workers is Postponed and Installed".

The reason why Kompas was chosen as the object of research is because of the uniqueness of Kompas, including speed, ease, and beauty which are the priority of the quality of information without losing its meaning. ${ }^{1}$ This is added because Kompas is currently the newspaper with the largest national circulation in Jakarta and Indonesia. Coupled with various awards, starting from 2005-2014. ${ }^{2}$

There are at least four functions of the mass media, namely: education, entertainment, information, persuasion, and supervision. ${ }^{3}$ In this case, the compass is in the information and monitoring function. The information function is in the PNS THR section which can be disbursed and labor THR can be postponed and paid in installments. Meanwhile, the monitoring function is seen from the reading of the discourse on social irregularities that have occurred. Civil servants and employers take priority over workers / laborers. Whereas when looking deeper, it is the workers / laborers who are experiencing a deep crisis, with the THR moment which at least will be used as a fulfillment of their daily needs, in fact the reality is reversed.

With this indication of irregularities, Critical Discourse Analysis (AWK)

\footnotetext{
${ }^{1}$ Alfiyya Dhiya Haq dan Efi Fadilah, "Transformasi Harian Kompas Menjadi Portal Berita Digita Subscription Kompas.Id", Jurnal Kajian Jurnalisme, Vol. 1, No. 2, 2018, 191.

${ }^{2}$ ttps://id.m.wikipedia.org/wiki/Kompas.

${ }^{3}$ Mahfudlah Fajrie dan Ika Suryanti Kusuma Dewi, "Framing Pemberitaan "Pembongkaran Pungkruk" Pada Surat Kabar Suara Merdeka", Jurnal An-Nida, Vol. 8, No. 1, 2016, 15.
} 
moves. There are at least four main objectives of AWK: first, analyzing discourse practices that reflect or construct social problems; second, diluting ideologies that bind language or words; third, increasing awareness to be sensitive to injustice, discrimination, and all forms of abuse of power; fourth, to help provide solutions to all the obstacles that hinder social change. ${ }^{4}$

Based on the explanation above, the indications of social or national irregularities serving workers that will be exposed by Fairclough's Critical Discourse Analysis must pay attention to three dimensions: text, discursive practices, and social praxis. Text is in all forms of linguistics. Discursive practice. Meanwhile, social praxis is usually embedded in broad socio-cultural goals, networks, and praxis. ${ }^{5}$

In order to be easy to understand and systematic, the research methods that the researcher will use are as follows:

This type of research used by researchers is a type of research library research (literature study). library research (library research) is a type of research that uses books, document magazines, journals, papers, the internet, and so on to obtain information related to the research under study. The author uses Norman Fairclough's critical discourse analysis with three dimensions, namely text, discursive practice, and socio-cultural praxis.

The collection technique uses the documentation method. The documentation method is the method of analyzing documents made by the subject himself or others, in the form of notes, pictures, or other people's work with the object of the May 11, 2020 edition of the Kompas article with the title of the article "Different Fate: THR PNS Cair This Week, THR Labor Delayed and Installed ".

\section{Norman Fairclough's Critical Discourse Analysis}

Critical discourse analysis seeks to analyze the discourse that is produced for social domination and how to fight the abuse of power. There are at least two disciplines that are very influential in critical discourse analysis, namely linguistics and social sciences. Linguistics helps in analyzing grammar, semantics, phonetics, and speech. Meanwhile, discourse as social praxis is 'neutral' and tries to interrogate institutions, organizations, group relations, structures, socio-political processes, communication, and interactions. This contact or relationship is called the semiosis process.

According to Fairclough's semiosis process, critical discourse analysis must pay attention to three dimensions: text, discursive practice, and social praxis. First, text. Text refers to speech, writing, graphics, and all linguistic forms of text. Second, discursive practice. Discursive practice refers to all forms of text production and consumption, so that it will lead to interpretation. Third, social praxis. Social praxis

\footnotetext{
${ }^{4}$ Haryatmoko, Critical Discourse Analysis (Analisis Wacana Kritis): Landasan Teori, Metodologi dan Penerapan (Depok: Rajawali Press, 2019), 14.
}

${ }^{5} \mathrm{Ibid}, 23$. 
refers to the aims, networks, and praxis of a broad social culture. ${ }^{6}$ The threedimensional model described by Fairclough is as follows:

Picture 1: Three-dimensional Fairclough AWK

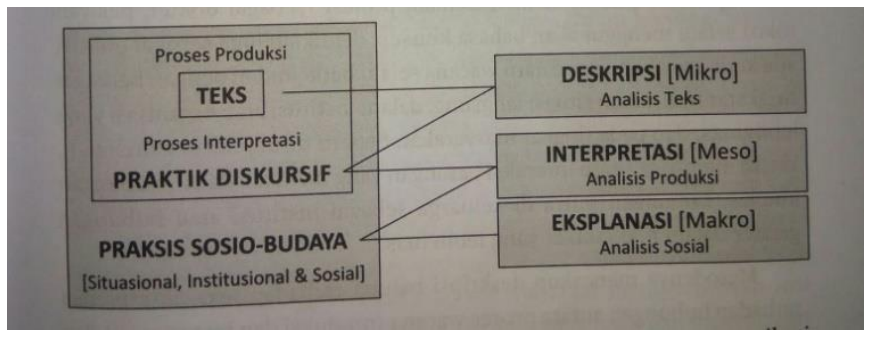

\section{Pers}

In the Big Indonesian Dictionary (KBBI) the press is news broadcasting media, such as newspapers, magazines, radio, television, and films. ${ }^{7}$ There are two definitions of the press, namely as follows: 1) In a narrow sense; The press is a printed media that includes newspapers, magazines, and newsletters at news agencies. 2) In a broad sense; Perception of all communication media, namely print media, audio-visual media, and electronic media. For example radio, television, the internet, and so on. Newspapers are included in the meaning of the press in a narrow sense. The press or media is needed by the government and the people in the life of the state. ${ }^{8}$

\section{Labor}

In the Big Indonesian Dictionary, laborers are people who work for others for a fee. ${ }^{9}$ Labor can also be understood as someone who works in a particular company, which is usually filled by people who can be categorized as a middle-lower class. There are many workers in Indonesia, due to the lack of jobs and Indonesia is still a developing country.

\section{SOCIAL-CULTURAL PRACTICE AND SOCIAL DISEASE ASSUMPTION}

Fairclough's Critical Discourse Analysis must pay attention to three dimensions: text, discursive practice, and social praxis. Text is in all forms of linguistics. The discursive practice is related to the form of production and consumption of text. Meanwhile, social praxis is usually embedded in broad social-cultural goals, networks, and praxis. ${ }^{10}$

${ }^{6}$ Ibid, 23.

${ }^{7}$ https//amp/s/kbbi.web.id/pers.html.

${ }^{8}$ Agung Suharyanto, "Surat Kabar Sebagai Salah Satu Media Penyampaian Informasi Politik pada Partisipasi Politik Masyarakat", Jurnal Administrasi Publik, Vol. 6, No. 2, 2016, 124.

${ }^{9}$ https//amp/s/kbbi.web.id/buruh.html.

${ }^{10}$ Haryatmoko, Critical Discourse Analysis, 23. 
The Minister of Manpower of the Republic of Indonesia Ida Fauziyah officially issued a circular on May 6, 2020 regarding the implementation of the provision of religious holiday allowances (THR) in 2020 at companies during the 2019 coronavirus disease (COVID-19) pandemic. This, of course, spreads reviews in various media, both pros, and cons. For example, in the brave media Kompas, the Monday, 11 May 2020 edition contained an article entitled "Different Fate: THR for Civil Servants This Week, THR for Workers is Postponed and Installed". With a title like that, it explicitly means that workers are becoming increasingly miserable and civil servants are fine, and people who own companies feel that they are benefited..

Table 1: Kompas article, Monday, May 11, 2020 edition

\section{Different Fate: THR for PNS Liquid This Week, THR for Workers is Postponed and Installed \\ Monday, 11 May 2020 | 16:33 WIB}

KOMPAS.com - The Ministry of Manpower and the Ministry of Finance have issued regulations regarding the holiday allowance (THR). However, there are substantial differences between the two policies. The Ministry of Manpower issued a circular that allowed the postponement of THR payments from employers to workers. In addition, THR payments are also allowed in installments. Meanwhile, the Ministry of Finance ensures that the provision of holiday allowances (THR) for the State Civil Apparatus (ASN), TNI, and Polri will be disbursed by Friday, May 15, 2020. So, how do the differences between the two policies affect the fate of workers and civil servants?

\section{THR for PNS Liquid This Week}

The THR granting does not apply to all civil servants, but applies to all officers and members of the National Police, judges and supreme judges who are equivalent to echelon III positions. However, echelon I and II employees, regional officials, state officials, presidents, ministers, DPR RI, and DPD will certainly not get THR. This THR is only given to all executors and all TNI, Polri, judges and supreme judges who are equivalent to echelon III positions. Echelon I and II are functionally equal and state administrators will not get THR, said Finance Minister Sri Mulyani.

Meanwhile, the amount of THR this year will be different from the previous ones, which includes the basic salary and inherent allowances, with the performance allowance not included in the 2020 THR component. To calculate the THR amount for civil servants, the value is calculated from the amount of basic salary received. PNS and the benefits attached to it. Based on Government Regulation (PP) Number 15 of 2019, the amount of basic salary for civil servants is tiered according to class and length of service known as class service period (MKG). The salary calculation from lowest to highest is adjusted based on years of service or MKG ranging from less than 1 year to 27 years. 
The amount of basic salary for class I civil servants (elementary and junior high school graduates), starting from him to Id, reaches Rp. 1,560,800 to Rp. 2,686,500. Meanwhile, for class II civil servants (SMP and D-III graduates), starting from class IIa to class IId, the value is Rp. 2,022,200 to Rp. 3,820,000. Class III civil servants (S1 to S3 graduates), ranging from class IIIa to class IIId, reach IDR 2,579,400 to IDR 4,797,000. Then, for class IV civil servants, starting from group IVa to group IVd, namely Rp. 3,044,300 to Rp. 5,901,200. The attached PNS allowances include child allowance, husband/wife allowance and meal allowance. The food allowance regulated in the Minister of Finance Regulation (PMK) Number 32 of 2018 is IDR 35,000 for groups I and II, IDR 37,000 for group III, and IDR 41,000 for group IV. Then civil servants also get a husband/wife in the amount of 5 percent of the basic salary. Finally, the child allowance, which is set at 2 percent of the basic salary per child, provided a maximum of three children.

\section{Labor Fate}

Regarding the THR for state servants who will soon be disbursed, the workers experience a different fate. Even though the government still asks companies to provide THR for their workers, the reality is not that smooth. Companies are allowed to pay THR in installments and even postpone it. Minister of Manpower Ida Fauziah issued a Circular (SE) on the Implementation of 2020 Religious Holidays in Companies during the 2019 Corona Virus Disease (Covid-19) Pandemic. Companies that are unable to pay THR to their workers on time are given two options. First, THR payments in stages for companies that are unable to pay in full. Second, companies that are unable to pay THR at all are allowed to postpone payments until the agreed time.

However, he emphasized that the company needs to have a dialogue with its workers to reach the agreement. The President of the Confederation of Indonesian Workers Unions (KSPI) Said Iqbal rejected the Minister of Manpower's (Menaker) Circular to provide leeway for employers not to pay the 100 percent THR. "KSPI is of the opinion that THR must be paid 100 percent for workers who come to work, workers who are temporarily dismissed due to Covid-19, workers who have been dismissed due to Covid-19, and workers who have been laid off during the D-30 period from Lebaran," said the President. KSPI Said Iqbal in his statement, Thursday (7/5/2020). However, Said Iqbal understands, several industries have also been hit by the Covid-19 pandemic. For this reason, he excluded companies with the category of small and medium enterprises, such as jasmine hotels, international non-franchise restaurants, MSEs, medium to lower scale retail, and so on.

Source: Kompas.com (Virdita Rizki Ratriani, Mutia Fauzia/Editor: Yoga Sukmana, Virdita Rizki Ratriani) 


\section{Text Dimensions}

In the article "Different Fate: THR for PNS Liquid This Week, Labor THR is Postponed and Installed". Indirectly, the Indonesian government seems to differentiate 'class' between civil servants and workers. Civil servants are given THR on time, while the workers must be postponed or even paid in installments, according to the agreement of both parties, both the company owner and the workers. In other words, the company owners benefit from this condition.

\section{Discursive Practice Dimensions}

Just before Hari Raya, every company or government must prepare it, it has become an inseparable routine. The condition in which "the workers' THR is postponed and paid in installments", the main cause is "covid-19". With the current "COVID-19", it is not only health that is of utmost concern, but also has an impact on the economy stays at home, social distancing, and PSBB which are enforced all over the world, including in Indonesia. What was questioned by people was that the THR effect did not reach the civil servants either, only the workers. So that the assumption arises, "the weak are always oppressed, that's the fate of the workers".

\section{Dimensions of Social Praxis}

Dengan asumsi tersebut, bukan tidak mungkin para pekerja akan melakukan demonstrasi dan hal-hal sejenis lainnya. Sebagai bentuk protes terhadap pemerintah yang terkesan berpihak pada satu pihak. Sebaiknya surat edaran itu dipantau dan disosialisasikan dengan baik, tindakan atau bentuk protes bisa dikurangi, atau bahkan tidak ada.

The social irregularity revealed in the article is that the workers' THR is postponed and can be paid in installments, thus increasing the misery of workers during the current pandemic, while civil servants receive THR on time and there is no prohibition, let alone until it is paid in installments like the workers. Of course, people will think that the government is pro to the company and does not accept the fate of the workers. Instead, the government wants to maintain the economic stability of the company owners, by not being too burdensome in offering (THR) from the company owners to the workers.

The obstacles that led to the irregularity were: first, related to "covid-19" which resulted in the workers being postponed and paid in installments by the owner. Second, civil servants as government officials who can be sure of adequacy, in fact the THR is on time. Any ongoing irregularities are desirable. Because two to one, two parties consist of the government and company owners, and the only one who works. The way to remove these barriers to insecurity is by controlling from the beginning to end, which is carried out by the government towards the company owners. Even so, it was postponed and in installments, the workers were given certainty. Because usually company owners playfully play with matters relating to 'money' at will. 


\section{CONCLUSION}

It can be seen that the three Fairclough dimensions and some of these assumptions can be identified and found in an article entitled "Different Fate: THR for Civil Servants of the Week, THR for Postponed and Installed Workers". Departing from the Fairclough dimension, namely: first, text, there is an article in the article that provides an understanding of the differences in the fate of civil servants and workers. Second, discursive practices, where workers are disadvantaged starting from "Covid-19" and government policies that seem to side with company owners and civil servants. Third, social practices, demonstrations, and the like can be suppressed by the socialization of good government and controlling the workers' THR to completion.

More than that, social irregularities occur, forming owners and civil servants, so that workers become victims. The obstacles that occur are due to the virus and the more concerned with people who are already enough 'civil servants' who are less 'laborers'. So that the irregularity is desired, because there are two camps: the government and the company owners, against one side: the workers. The way to remove these obstacles: control by the government of company owners related to THR and so that it can be accelerated.

\section{REFERENCE}

Bahtiar, Rais Agil dan Juli Panglima Saragih. “Dampak Covid-19 Terhadap

Perlambatan Ekonomi Sektor UMKM". dalam Info Singkat. Vol. 7. No. 6.

Fajrie, Mahfudlah dan Ika Suryanti Kusuma Dewi. "Framing Pemberitaan "Pembongkaran Pungkruk" Pada Surat Kabar Suara Merdeka". dalam Jurnal An-Nida. Vol. 8. No. 1, 2016.

Haq, Alfiyya Dhiya dan Efi Fadilah. “Transformasi Harian Kompas Menjadi Portal

Berita Digita Subscription Kompas.Id". dalam Jurnal Kajian Jurnalisme. Vol.1.

No. 2, 2018.

Haryatmoko. Critical Discourse Analysis (Analisis Wacana Kritis): Landasan Teori, Metodologi dan Penerapan. Depok: Rajawali Press, 2019.

http://kbbi.web.id/buruh

http:// kbbi.web.id/pers

https://id.m.wikipedia.org/wiki/Kompas_(surat_kabar)

https://www.google.com/amp/s/blog.hactiv8.com/dampak-pandemi-virus

corona-bagi-industri-indonesia/amp

Rahman, Abdul. Pendidikan Agama dan Pengembangan untuk Bangsa. Jakarta: PT. Raja Grafindo Persada. 2005.

Suharyanto, Agung. “Surat Kabar Sebagai Salah Satu Media Penyampaian Informasi Politik pada Partisipasi Politik Masyarakat". dalam Jurnal Administrasi Publik. Vol. 6. No. 2, 2016. 